\title{
Examining the community perceptions on the Corporate Social Responsibilities of the mining companies in Kahama District, Tanzania
}

\author{
Esther Joseph Ikasu e.ikasu@hotmail.co.uk
}

\begin{abstract}
This study examined the community perceptions regarding the engagement of mining companies in corporate social responsibility activities and motive driving the companies to fulfill their corporate social responsibilities using the Carroll's Pyramid of corporate social responsibility. The study was conducted in Bugarama ward, Kahama district in Tanzania. Data were collected using a structured questionnaire with 100 randomly sampled household level respondents and analyzed for descriptive statistics. The findings revealed the engagement of the company in a range of corporate social responsibility activities ranging from the ones that were conveniently beneficial to communities to those that were rationally organized. Economic success was found to be the most important motive. The desire to be identified as ethical and fulfilling philanthropic expectations of the communities had some links with economic profitability and business sustainability. On the other hand, the desire to comply with the laws was found to have the least link with engagement in corporate social responsibility. From these findings, it is concluded that corporate social responsibility is a strategic investment that seek to strengthen social capital. Behind ethical and philanthropic responsibilities appears to be the economic responsibilities that businesses seek to achieve Key words: Corporate Social Responsibility, Community, Pyramid, Motive, Tanzania
\end{abstract}

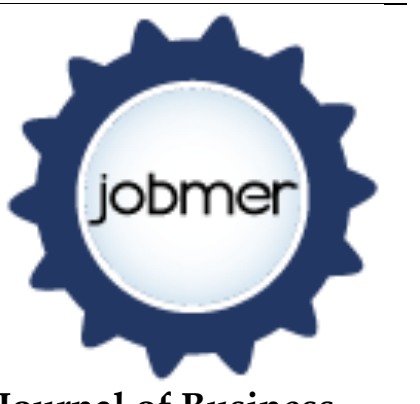

Journal of Business Management and Economic Research Vol.2, Issue.7, 2018 pp.12-31

Doi: 10.29226/TR1001.2018.46 


\section{Introduction}

Corporate-community relations has recently grown into an important focus in public and business administration research. Corporate Social Responsibility (CSR) is not only treated as a research and knowledge area but also as one of the major principles (Belal, 2016) if not best practices that guide the interaction between businesses and societies in modern states. In many of the countries, CSR has been incorporated in the existing laws that guide establishment and operation of business enterprises. Business are required to make sure that their operations improve the wellbeing and environments of the societies around them (Gamu \& Dauvergne, 2018). In other countries, CSR is perceived as a good practice that presents the business entities as having connection with the social lives of the communities and concerned with communities' welfare, livelihood, and the general social and economic development (Ratner, 2001). While the first conception insist on the desire to encourage the businesses to fulfill their legal responsibility, the later insist the view that the separation between the business and social worlds is narrow and thus business actors need to be corporate citizens who hold a sense of responsibility (Cronin, 2018).

Despite the growing consensus that businesses need to engage in CSR activities, the practices and perceptions related to CSR differ across countries and communities (Matten \& Moon, 2008). Owing to these variations, CSR tend to take different forms ranging from a contractual obligation to benefit the communities to a voluntary solicitation of trust and legitimacy in the communities (Idemudia, 2007). While the growth of CSR activities is perceived as a necessary, there is no objectively accepted explanation to why companies engage in CSR. The lack of a common ground for explaining why businesses should engage in CSR increases the need for scholarly enquiries to understand the motivations behind engagement of businesses in CSR activities in different social, political, and economic contexts.

The paradox surrounding the question whether CSR is an obligation of the businesses or just an option has invited endless debates which necessitate the need to answer another related question, especially why are the businesses increasingly being engaged in CSR activities. Scholars such as Ni \& Van Wart (2015) look at CSR as the attempt to do good in order to do well. Doing good to do well implies that what is seen as a 'responsibility' of the businesses has a hidden motivation behind. In other words, the attraction to be seen good in the 
eyes of the communities, which CSR displays is the rational desire to attain economic goals such as increasing profitability and market share (EdingerSchons, Lengler-Graiff, Scheidler, \& Wieseke, 2018; Gamu \& Dauvergne, 2018). In this point of view, the assumption is largely that businesses use CSR as a strategic tool for achieving business economic aims and interests.

A different view is presented by Gupta, Briscoe, \& Hambrick (2017) who argue that the advancement of CSR in a company is largely determined by the companies' ideological orientations. This means that the degree at which the business will be engaged in CSR activities will differ not only because of the difference in the desire to achieve better financial results, but rather the orientation towards the culture of contributing to the fulfillment of social needs. This position can also be associated with the need to behave as good corporate citizens who must respect the values and norms of the communities as well as fulfilling the social expectations of the communities (Garriga \& Mele, 2004; Ahn \& Park, 2018). The two closely related arguments associate CSR fulfillment with both the ethical and philanthropic orientation of CSR in business.

On the other hand, there are those who see CSR as the fulfillment of the compulsory obligation imposed upon the businesses by the law to ensure that the businesses give back to communities in exchange with their financial gains (Ali, W, Frynas \& Mahmood, 2017; Schmitz \& Schrader, 2015). The argument in connection with this position is that the engagement in CSR is not voluntary. It is assumed that in communities where there are no laws for enforcing CSR as a requirement, businesses' engagement in CSR activities will generally be low. In the light of these varying views, the need arises to understand what motivates the businesses to engage in CSR paying attention to the local contexts of the communities including their awareness, experience, and perceptions regarding the fulfillment of CSR.

\section{Purpose of the Study}

The aim of this study was to examine the community perceptions on the fulfillment of CSR by mining companies in Bugarama, Kahama district. To achieve this, guided by the Carroll's' pyramid of CSR, the analysis focused on the key CSR approaches, community members awareness, and the perceptions of community members regarding the duty of the companies to fulfill their CSR in the communities. Specifically, the study sought to identify the existing CSR activities in the community, understand the community members' awareness of 
CSR, and assess the perceptions of local community members regarding the reasons for the mining companies' engagement in CSR.

\section{Conceptual ground}

Like most of the management concept, CSR does not have a single objective definition. As Matten \& Moon (2008) observed, the concept is characterized by dynamics across time and places. Even for researchers who have carried out studies on CSR practices overtime such as Archie Carroll have revealed the need to look into new dimensions and practices across societies and countries (See Carroll, 1991; 1999; 2016). There are two ways of looking at CSR, which also necessitates looking at it in two different ways. These are the narrow and broad approaches. In a narrow approach, CSR is confined to the fulfillment of legal requirements specified by governments and authorities to ensure that businesses processes do not cause harm on societies or the negative effects are mitigated by businesses (Marika, Magutu, \& Munjuri, 2017).

On the other hand, the broad perspective looks at CSR as a broad range of theories, approaches, processes, and practices which recognize and seek to ensure that businesses have a duty to society and need to maintain good relationship with societies (Carroll, 2016). It generally entails success of the business without endangering people's wellbeing, respecting social norms, and protecting the natural environments (Adetunji \& Ogbonna, 2013). While the first conception place emphasis on the legality of CSR, the later treats it as not necessarily limited to the obligations of the businesses that are specified by business regimes. It suggests that there is a sense of responsibility that the business world owes to the social and natural world and thus need to be good to the societies and their natural environments. With this conception, business entities are expected to interact positively with the societies even if there are no specific laws that require businesses to engage in CSR activities.

The design and analysis of in this study were guided by the Pyramid of Corporate Social Responsibility by Archie Carroll. Carroll's pyramid of CSR provides an influential framework for both defining CSR and explaining why businesses engage in activities that constitute what is known as CSR. Carrol (1991) identify businesses with four types of responsibilities, which he arranges in an order a pyramid, especially from the more basic and expedient to those that are more advanced and seemingly intricate. In that order, economic responsibilities are the basic and more likely followed by legal responsibilities, 
then ethical responsibilities, and finally philanthropic responsibilities (Carrol, 1991; 1996). Therefore, corporations will seek to fulfill their responsibilities in a pyramidal order as figure 1 shows.

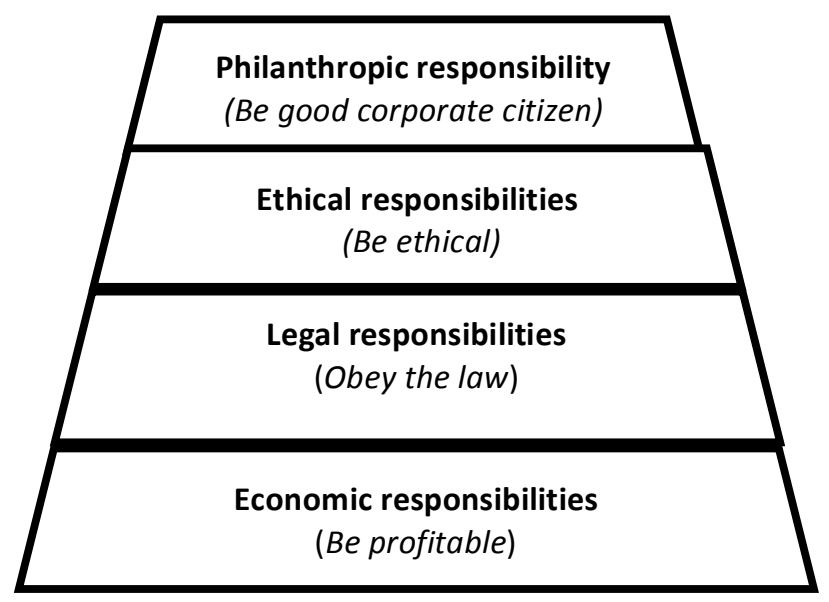

Figure 1: Carroll's pyramid of corporate social responsibilities

According to the Carrol's pyramid of CSR, becoming profitable is the most basic and obvious responsibility of corporations. Therefore, before thinking about respecting authoritative rules and acting in accordance with the need to fulfill social expectations, the corporations will always be concerned with being profitable and attaining economic success. In other words, corporations give in order to be profitable and remain profitable (Carroll, 1991). Next to the economic responsibilities, corporations will act in the way that they should fulfill their legal responsibilities. The assumption attached to these responsibilities is that the fulfillment of legal responsibilities relates to obeying and observing the supreme authoritative rules including the laws and regulations of the country (Frynas \& Yamahaki, 2016). This implies that corporations are more likely to engage in CSR if there are laws that require them to do so and there are mechanisms for enforcing such laws (Alvarado-Herrera, Bigne, Aldas-Manzano \& Curras-Perez, 2017). Therefore, the rules that specify the obligations of the businesses and how they should interact with communities that surround them need to be in place, and communities have to be aware of such rules.

The next category of responsibilities in the order are the ethical responsibilities. These responsibilities have to do with the need to observe, respect, and act in 
agreement with the social and cultural norms of the communities. The assumption is that businesses will also opt to do what appears to be socially right even if they are not compelled by the laws (Idemudia, 2007). The last in the order are philanthropic responsibilities. These relate to the need of corporations to contribute towards attaining social goals of the societies and communities around them, which is based on the concern for the wellbeing of the communities and addressing social atrocities such as poverty and diseases (Carrol, 1999). When this order is followed, it is more likely to assume that the mining companies will be concerned with ethical and philanthropic responsibilities following the fulfillment of economic and legal responsibilities (Carrol, 1996). Alternatively said, philanthropic giving is subject to an assurance that there are some economic returns. Similarly, the desire to fulfill the legal obligations and expectations of government authorities needs to be considered side by side with the fulfillment of the businesses financial and economic goals.

\section{Some evidence from previous studies}

Different studies in the area of CSR have focused on the motivation of the businesses to engage in CSR activities. Some of these studies were more relevant since they were guided by the classification of CSR motives according Carroll (1991). Ramasamy \& Yeung (2009) in a self-administered survey on the Chinese consumers' perceptions of CSR found that the Chinese consumers were more supportive to corporate responsibilities. Of the four types of responsibilities, especially economic, legal, ethical, and philanthropic; the findings revealed that economic responsibilities were the most important while philanthropic responsibilities were the least important for the consumers. Related to the economic motives, the recent study from Kenya revealed that companies used CSR as a means for attracting graduate employees to join them (Marika, Magutu, \& Munjuri, 2017). A related observation is provided by Loosemore \& Lim (2017) who found a close linkage between engaging in CSR activities and the efforts to enhance the financial performance of the business enterprises.

On the other hand, some studies show that laws have been instrumental for ensuring that businesses have a positive impact on social development. For instance, Carroll (2016) presents recent evidence of consistency between the assumptions of the pyramid approach and the CSR practices in the US. He argues that CSR is attributed to five main motives. These are to perform in consistency with low, complying with state regulations, acting as law abiding 
citizens, fulfilling legal obligations to stakeholders and societies, and providing goods and services that meet legal standards.

Despite the fact that the evidence available have not been able to challenge the primacy of the economic motives behind engaging in CSR, it is also becoming evident that the presence of the laws and their effective implementation could help to strike a balance between the hidden economic motive and the usually displayed ethical and philanthropic motives of CSR activities in the communities (Devin \& Richards, 2018). Reflecting on the previous studies, it is important to consider all the four categories of CSR motives as perceived by communities in a specific social economic setting. The next section provides a synthesis of the methods through which the study was carried out.

\section{Methods}

\section{Approach and design}

A descriptive cross-sectional design was employed for the purpose of this study. According to Omair (2015), a descriptive study design serves two important roles in research. First, it can be used to understand the distribution of characteristics in a selected study sample. Secondly, it may be used to understand characteristics of the study objects, which may be generalized to provide the lesson for related or similar populations or contexts. On the other hand, a cross sectional design focuses on observed characteristics of a phenomenon at a given point in time (Creswell et al, 2013). The intention of the study, which was to understand how a specific community under the study perceived the reason for the fulfilment of CSR determined the choice of the study design. However, the findings of the study could be useful for explaining the reasons and motives for engagement of businesses in CSR activities in other communities, especially the rural communities which have been integrated into large scale mining investment both within and outside Tanzania.

\section{Study area}

The study was conducted in Bugarama ward in Kahama District in Shinyanga region. Bugarama is one of 35 wards of Kahama district. The other wards are Bukomela, Bulige, Bulungwa, Bulyanhulu, Busangi, Chambo, Chela, Chona, Idahina, Igunda, Igwamanoni, Isaka, Jana, Kashishi, Kinamapula, Kisuke, Lunguya, Mapamba, Mega, Mpunze, Mwalugulu, Mwanase, Ngaya, Ntobo, Nyankende, Sabasabini, Segese, Shilela, Ubagwe, Ukune, Ulewe, Ulowa, 
Ushetu, and Uyogo. The ward has six villages namely Bugarama, Buyange, Bunango, Igadija, Igwamanoni, Ilogi. The ward was selected because of the fact that four of its villages, namely Bugarama, Ilogi, Buyange, and Bugwamanoni are encompassed in the famous Bulyanhulu Gold Mine (BGM), which started its operations in 2001 replacing artisanal miners who had occupied the areas for 26 years since gold was discovered in the area. The villages which were involved in the study were Bugarama and Ilogi. The reason for selecting these villages is that, the largest part of their populations directly interact with the BGM and its employers as part and parcel of the two communities. In this study, the two villages are treated as a single community due to the similarity they have owing to the development of mining activities and related economic life.

\section{Study population and sampling}

The study targeted the local community members who had been in the communities around the gold mine. All adult member who had attained the age of 18 during the study qualified to be part of the study. The sampling frames, which had lists of all households in the villages were obtained from the village authorities and systematic random sampling was used to select 50 households for each of the two villages. The households for each of the village were divided in two categories where 25 of them were to produce male participants and 25 female participants. The final study sample included 100 respondents who were selected using simple random (rotary) sampling for each of the households. The selection of a respondent at household level involved listing the names of all eligible members on pieces of papers, mixing them, and finally picking one of them to be included in the sample.

\section{Data collection tools and procedure}

Data for this study were collected using a structured questionnaire with 41 close-ended questions. The first 10 items in the questionnaire sought to collect data related to the social-demographic characteristics of respondents including age, sex, education, income, occupation, marital status, and employment history of the respondents. These were important for examining the perceptions across social demographic groups in the sample. The next nine items sought to document the respondents' awareness and experiences regarding the engagement of mining company in CSR activities. Some common social economic development activities of the communities were identified and the 
respondents were asked to score the companies between 1 and 10 based on the extent to which the mining company was engaged in supporting those activities. In the next twenty items presented the reasons which motivate businesses to engage in CSR activities based on the Carroll's pyramid of corporate social responsibility in four categories, especially economic, legal, ethical, and philanthropic responsibilities. The respondents were asked to score the items between 1 and 10. The last two questions assessed the extent to which the respondents thought they were responsible for demanding the company to fulfill its CSR and the extent to which the company itself had a sense of responsibility. The respondents were asked to choose between 'less responsible' and 'highly responsible'. The administration of the questionnaire ended between 20 and 30 minutes each.

\section{Data analysis}

The analysis of data was done quantitatively. The questionnaire was coded and the responses were entered in the Statistical Package for Social Sciences (SPSS). Frequency tables were generated to compare the scores across different social demographic groups of respondents. Descriptive statistics were used to compare the scores of the company across the nine common areas of CSR activities in the study community and the variations in perceptions regarding the four categories of corporate social responsibilities. A comparison of the scores across the four categories of CSR motivations was done in the light of the literature and in particular the Carrol's (1991) pyramid of framework. Arguments and conclusions linked to the study objectives are supported by descriptive statistical analysis.

\section{Results and Discussion}

The study sought to examine the community perceptions regarding the engagement of mining companies in CSR activities and the perceptions regarding the motive that drive the companies to fulfill their corporate social responsibilities. In doing so, the entry point was to identify the existing CSR activities and the ways in which they are perceived and conceived by communities. However, there was a recognition that taking a stock of the social demographic characteristics of respondents would be crucial since the perceptions regarding the responsibility of institutions can be influenced by social demographic differences among community members, which the next subsection focuses on. 


\section{Social demographic characteristics of questionnaire respondents}

Six variables were considered in this respect. These were sex, marital status, age, education, employment status, household income, and social position of the respondent. Table 1 provides a breakdown of the respondents by their key social demographic characteristics.

Table 1: Respondents' social demographic characteristics

\begin{tabular}{|c|c|c|}
\hline & Variable: Categories & Percent \\
\hline \multirow[t]{2}{*}{ Sex: } & Male & 50.0 \\
\hline & Female & 50.0 \\
\hline \multirow[t]{4}{*}{ Marital status: } & Single & 55.0 \\
\hline & Married & 32.0 \\
\hline & Others & 4.0 \\
\hline & Widowed & 9.0 \\
\hline \multirow[t]{5}{*}{ Age category: } & 18-35(young age) & 48.0 \\
\hline & 36-50(young adult) & 37.0 \\
\hline & 51-59(mature adults) & 7.0 \\
\hline & 60-70 (old age) & 7.0 \\
\hline & 71 or above (elderly) & 1.0 \\
\hline \multirow[t]{5}{*}{ Education: } & $<$ Primary education & 6.0 \\
\hline & $=$ Primary education & 33.0 \\
\hline & Secondary education & 36.0 \\
\hline & Higher education (non-university) & 21.0 \\
\hline & University/college education & 5.0 \\
\hline \multirow[t]{3}{*}{ Employment status: } & Currently employed & 22.0 \\
\hline & Currently not employed & 74.0 \\
\hline & Retired & 4.0 \\
\hline \multirow[t]{4}{*}{ Household income: } & Very low< 15,470TZS) & 6.0 \\
\hline & Low $>15,470<30,940 \mathrm{TZS}$ & 43.0 \\
\hline & Average $=(30,940$ to $46,410 \mathrm{TZS})$ & 47.0 \\
\hline & High $>46,410$ TZS & 4.0 \\
\hline \multirow[t]{4}{*}{ Social position: } & None, just an average citizen & 86.0 \\
\hline & Faith or religious leader & 4.0 \\
\hline & Local government leader & 6.0 \\
\hline & Big business owner/influential & 4.0 \\
\hline
\end{tabular}

As table 1 reveals, the study included 100 respondents whose $50 \%$ were male and $50 \%$ were females. Fifty-five percent of the respondents were single, $32 \%$ were married, while the remaining were either widowed $(9 \%)$ or were in other marital status groups including divorced. In terms of the age, the majority were 
either young (48\%) or young adult (37\%) age groups, which meant 18-35 and 3650 years respectively. Of the remaining, $7 \%$ were in the 51-60 years' age group, the other $7 \%$ were in the $61-70$ age group while only one had attained 71 . This age distribution reflects the youthful age composition of the study community, which many of the interviewed community leaders associated with recent immigration that accompanied the increase of mining activities in the area.

In terms of education, the majority of the respondents had secondary education $(36 \%)$ while $33 \%$ had primary education. The respondents who had higher education constituted $26 \%$ of the sample including a few who had university education (5\%) and those who had other forms of higher education apart from university education. According to interview respondents, this is again attributed to the influx of the young school graduates into the community in search of improved livelihood and the limited willingness to engage in agrarian activities. Regarding employment status, only a small proportion (22\%) identified themselves as employed while the majority, $74 \%$ reported not to be employed. The remaining $4 \%$ were retirees. In case of the income, the majority $(90 \%)$ reported to belong to households which were earning a monthly income equals to $(47 \%)$ or lower than $(43 \%)$ the average rural household income, which was 30,940-46,410 Tanzanian shillings. Further, the social economic positions of the respondents in the community, which could also influence both the knowledge and perceptions regarding CSR was considered. The majority, 86\% were average citizens who did not hold any leadership position in the community, $6 \%$ had held or were holding positions in grassroots' authorities, $4 \%$ were religious and spiritual leaders, and the remaining $4 \%$ were influential business owners in the communities. Therefore, these difference provided a good mix of social demographic characteristics which needed to be compared in terms of influencing the awareness, perceptions, and the reasons for fulfillment of CSR by mining companies. The next section focuses on community's experiences of existing CSR activities.

\section{Awareness and experience of existence of CSR activities.}

The other important objective of the study was to identify the existing CSR activities from the experiences of community members. Through interviews, it was found that almost all the community level officials and leaders were informed of both the importance and the need for mining companies to engage in 'supporting' social and economic development of the communities around 
them. Both grassroots bureaucratic officials and elected community leaders thought it was a responsibility of big businesses to allocate part of their income for supporting social and economic development in the communities. Based on the interviews, nine sets of CSR related activities were identified. The activities identified were further included in the scoring questionnaire. The results of the scores are summarized in Table 2.

Table 2: The most common CSR activities carried out by mining companies

\begin{tabular}{lrrrrr}
\hline Key focus of CSR activities in the communities & Scores & $(\%)$ & Mean & Std. Error & Std. Deviation \\
\hline Economic engagement (employment, capital) & 760 & 18.45 & 7.60 & .248 & 2.482 \\
\hline Supporting the disadvantaged (poorer and disabled) & 576 & 13.98 & 5.70 & .312 & 3.127 \\
\hline Construction of offices of LGAs and roads & 564. & 13.69 & 5.64 & .293 & 2.938 \\
\hline Construction of education facilities & 481. & 11.68 & 4.81 & .297 & 2.977 \\
\hline Water supply systems & 448. & 10.88 & 4.48 & .282 & 2.826 \\
\hline Water and sanitation in schools & 432. & 10.49 & 4.32 & .281 & 2.813 \\
\hline Sponsorship for school children from poor families & 425. & 10.32 & 4.25 & .294 & 2.941 \\
\hline Political activities such as elections & 243 & 5.90 & 2.43 & .190 & .139 \\
\hline Constructing worship houses (churches, mosques) & 190. & 4.61 & 1.90 & & 1.396 \\
\hline Total & 4119 & 100.00 & & &
\end{tabular}

The results in Table 2 indicate that the communities recognize in supporting community-level development initiatives and activities. The indirect supports for allowing the communities to engage in economic activities including employment and mobilizing capital had the highest score that accounted $18.45 \%$ of the 4119 total scores. The mean score was 7.60 (SD=2.242). Supporting disadvantaged groups including the poor and disable and construction of public infrastructures such as roads and offices of LGAs had relatively high scores accounting up to $13.98 \%$ and $13.69 \%$ and the mean scores of $5.70(\mathrm{SD}=3.127)$ and $5.64(\mathrm{SD}=2.938)$ respectively. Similarly, the contribution to the construction of education facilities had a relatively high score $(4.81, \mathrm{SD}=2.977)$, which was above the average of the mean score (4.57).

On the other hand, the engagement of the mining companies in supporting religious and political activities such as construction of worship houses and financing electoral campaign rallies was found to be low with the mean scores of $(1.90, \mathrm{SD}=1.396$ and $2.43, \mathrm{SD}=1.908)$ respectively. Close to the average of the mean score, were the supports related to water supply, water sanitation in schools, and sponsoring education for children from poor households, which 
had the mean scores of $4.48(\mathrm{SD}=2.826), 4.32(\mathrm{SD}=2.813)$, and $4.25(\mathrm{SD}=2.941)$. These findings indicate that CSR of the mining companies are largely convenient and in most cases focus on development sectors, which are likely to create appreciated impact in the communities. These include economic empowerment initiatives, which in addition to the responsibility of the companies to support them are sought by community members themselves to ensure economic survival. They also target areas that are more likely to capture high attention of both the communities and their authorities such as education and poverty. In this respect, it is feasible to argue that the communities are aware of that the mining companies engage in CSR activities, and indeed their engagement tend to vary across community development issues and sectors. Subsequently, this raises the need to understand, from the view point of community members, why the companies engage in CSR activities.

\section{Perceived reasons for CSR}

The perceptions relating to the essence and reasons why mining companies engage in CSR activities were assessed in the light of the Carroll's Pyramid of Corporate Social Responsibilities. The aim was to determine which of the four levels of CSR namely economic responsibilities, legal responsibilities, ethical responsibilities, and philanthropic responsibilities may best explain why the mining companies engage in CSR activities identified in the study community. Each of the four group of responsibilities included five interrelated reasons associated with engaging in CSR activities, which the respondents had to score along a scoring scale of 1 to 10. Table 3 provides the results of the analysis, which include the total scores for each of the reasons in each category and their sums, percentage of the scores contributed by each of the perceived reason in a group, the mean scores for each reason and each group and the standard error and standard deviation. 
Table 3: Comparison of individual and group scores

\begin{tabular}{|c|c|c|c|c|c|}
\hline Economic responsibilities: & Score & $(\%)$ & Mean & Std. error & $\begin{array}{r}\text { Std } \\
\text { deviation }\end{array}$ \\
\hline To maintain strong competitive position & 819 & $(22.66)$ & 8.19 & 0.187 & 1.873 \\
\hline To get as much profit as possible & 812 & $(22.47)$ & 8.12 & 0.188 & 1.876 \\
\hline It helps them to maximize earning per share. & 785 & $(21.72)$ & 7.85 & 0.190 & 1.90 \\
\hline To maintain a high level of operating efficiency & 690 & $(19.09)$ & 6.9 & 0.206 & 2.057 \\
\hline To get respect that they are consistently profitable & 508 & $(14.06)$ & 5.08 & 0.205 & 2.048 \\
\hline Sum average & 722.8 & $(20.00)$ & 7.22 & 0.195 & 1.952 \\
\hline \multicolumn{6}{|l|}{ Legal responsibilities: } \\
\hline To be defined as the ones that fulfil legal obligations & 552 & $(28.09)$ & 5.52 & 0.232 & 2.325 \\
\hline Provide goods \& services that meet minimum legal requirements & 437 & $(22.24)$ & 4.37 & 0.225 & 2.255 \\
\hline To be law abiding corporate citizens & 413 & $(21.02)$ & 4.13 & 0.250 & 2.497 \\
\hline To be consistent with expectations of government & 392 & $(19.95)$ & 3.92 & 0.244 & 2.444 \\
\hline To comply with regulations of the central and local authorities & 171 & $(8.70)$ & 1.71 & 0.109 & 1.085 \\
\hline Sum average & 393 & $(20.00)$ & 3.93 & 0.212 & 2.121 \\
\hline \multicolumn{6}{|l|}{ Ethical responsibilities: } \\
\hline To prevent compromising the social norms-may affect goals & 734 & $(25.29)$ & 7.34 & 0.236 & 2.362 \\
\hline To make good citizenship be defined as acting morally right & 593 & $(20.43)$ & 5.93 & 0.245 & 2.451 \\
\hline $\begin{array}{l}\text { To make corporate integrity and ethic transcend mere } \\
\text { compliance }\end{array}$ & 572 & $(19.71)$ & 5.72 & 0.242 & 2.421 \\
\hline To recognize and respect newly revolving ethical norms & 517 & $(17.82)$ & 5.17 & 0.251 & 2.511 \\
\hline To perform in a way that they respect social norms and mores & 486 & $(16.75)$ & 4.86 & 0.232 & 2.318 \\
\hline Sum average & 580.4 & $(20.00)$ & 5.80 & 0.241 & 2.413 \\
\hline \multicolumn{6}{|l|}{ Philanthropic responsibilities: } \\
\hline $\begin{array}{l}\text { Just to assist in whatever makes community happy (e.g. fine and } \\
\text { arts) }\end{array}$ & 635 & $(24.23)$ & 6.35 & 0.252 & 2.520 \\
\hline $\begin{array}{l}\text { Voluntarily contribute to projects that are for improving quality } \\
\text { of life }\end{array}$ & 608 & $(23.20)$ & 6.08 & 0.242 & 2.419 \\
\hline $\begin{array}{l}\text { A sense of social duty to assist public and private (social) } \\
\text { institutions }\end{array}$ & 515 & $(19.65)$ & 5.15 & 0.236 & 2.363 \\
\hline $\begin{array}{l}\text { Make managers participate in charitable works of the } \\
\text { communities }\end{array}$ & 477 & $(18.2)$ & 4.77 & 0.217 & 2.174 \\
\hline To be consistent with the charitable expectations of communities & 386 & $(14.73)$ & 3.86 & 0.190 & 1.896 \\
\hline Sum average & 524.2 & $(20.00)$ & 5.24 & 0.227 & 2.274 \\
\hline
\end{tabular}

The four group of corporate social responsibilities in Table 3 need to be examined in a comparative way. What can be clearly observed is that the scores for nearly all the vive items that constitute economic responsibilities were closely equal (except the last in the order) and were close to the expected average score which was $722.8(20 \%)$. This suggests that all the five reasons in the economic responsibilities' category have an important contribution to the desire of mining companies to engage in CSR activities. By looking at the sum averages of the mean scores in the fourth column, it is revealed that economic responsibilities had the largest mean score $(7.22, \mathrm{SD}=1.952)$, followed by ethical responsibilities (5.90, $\mathrm{SD}=2.413)$, then philanthropic responsibilities (5.24, $\mathrm{SD}=2.274)$. Legal responsibilities had the least mean score $(3.93, \mathrm{SD}=2.121)$. These results show that the engagement of mining companies in corporate social 
accountability activities is more motivated by economic and ethical reasons compared to legal and philanthropic motives. However, a father grasp of the pattern of these results may not be easy without understanding the interaction between these four groups of responsibilities and their related motives. This can be best done as part of the general discussion, which the next section presents.

\section{General Discussion of Findings}

The study has examined the community experiences relating to the engagement of mining companies in CSR activities and the perceptions regarding the motive that drive the companies to fulfill their corporate social responsibilities. The findings have revealed the existence of several ways in which the companies engage CSR and are considered to support community development activities, initiatives, and efforts. The ways in which the communities benefit from the existence of the mining companies range from contingent economic facilitation, which include ad hoc employment and income earning activities which are growing in the community due to the existence of the mining companies and their employees to rationally organized support to communal services projects such as education, water, and developing transport infrastructure.

These findings support previous studies that have found varying and overlapping forms of corporate responsibility that may be associated with different motives. Porter \& Kramer (2006) for instance found that because of the interdependence between economic and social life, CSR may take different forms ranging from an affirmative action to address a social harm to strategic initiatives for ensuring success and continuity. These forms can be both implicit and explicit (Matten \& moon, 2008) or both rationally planed and circumstantial and contingent as the findings have revealed (Husted \& Allen, 2007). However, these different forms are all likely to manifest themselves under a single umbrella that includes positive actions directed towards supporting development of the communities.

Further, the findings have revealed that communities perceive most of the CSR activities as having an economic motivation rather than a humanitarian and philanthropic motivation. While these findings agree with previous studies by Carrol (1995) and Devin \& Richards (2018), they can be questioned if considered in line with the findings of the study by Hasan, Kobeissi, Liu. \& Wang (2018) whose recent study revealed that the engagement of the businesses in CSR 
activities becomes possible if the business is productive. In other words, economic success, apart from being a motive is also a driver of CSR. In addition, there appear to be a close linkage between the quest to be attuned with moral standards of the communities and achieving greater acceptability and legitimacy (Garriga \& Mele, 2004; Ahn \& Park, 2018). This has been identified as one among the most effective techniques and tools used by businesses to maintain good relationship with communities and therefore be able to achieve their economic goals including profitability, market stability and competition, and productivity. Therefore, the distinction between economic motives and fulfilling ethical responsibilities may not be as sharp as suggested by Carroll (1991). The two are highly overlapping.

In addition, what the findings have suggested that legal responsibilities are of a list concern appears to be supported by previous studies, especially when one takes into account the capacity of community-level actors to demand large businesses to fulfill their legal responsibilities. In some cases, studies have found that awareness of the laws that empower communities to demand that business entities should fulfill their responsibilities is limited (Gamu \& Dauvergne, 2018). The findings from this study generally increase our understanding of the communities' perceptions on why are profit making companies contribute to community development efforts. It is notable from the study that businesses may not be as altruistic as simply assumed in the philanthropic view of CSR. The choice of what the businesses should support as part of social development may be determined by productivity and the need to maintain status quo. Therefore, the existence of legislations that require companies to engage in CSR activities may not guarantee positive contribution of CSR to the improvement of social welfare (McWilliams \& Siegel, 2001; Schwartz \& Carrol, 2003). This is mainly because the primary goal of all businesses, as opposed to public organizations is to make some profits.

\section{Conclusion}

As suggested by findings of previous research and the current study, the businesses are more likely to give if they have received or they have a legitimate expectation to gain from giving. This logical relationship between corporate social responsibilities of business success make the two tactically and strategically interdependent. However, the general tradeoff in this relationship is whether the businesses would like to treat their engagement in CSR activities 
an anonymous and compassionate virtue that could be kept secret and not known to communities, other businesses, and governing authorities. Probably this is not a case in the world of business. However, since knowledge is unlimited, contextual, and dynamic, further research is required to test the hypothesis whether successful businesses are more likely to engage in CSR supports when the information regarding their engagement is likely to reach a wider audience compared to environments where the audience is limited or inexistent. This is recommended as an area for further research.

While creating environments for profitability and continued growth is a primary concern of the business institutions, CSR may take a form strong engagement in humanitarian and ethical support to communities if such engagement has a potential of making them loved in the eyes of not only the communities, but also the other businesses and the world at large. In that case, the idea that businesses would engage in CSR activities when they are continuously making loss or without expectations of recovering from such losses may not intellectually work. The take-home message in this respect is that, behind the engagement of any business in CSR activities there is always a question of creating better environments to be recognized, appreciated, trusted, and relied upon. With this idea, CSR stands as a tactical and strategic social investment by businesses.

\section{References}

Ahn, S. Y., \& Park, D. J. (2018). Corporate Social Responsibility and corporate longevity: The mediating role of social capital and moral legitimacy in Korea. Journal of Business Ethics, 150(1), 117-134.

Ali, W., Frynas, J. G., \& Mahmood, Z. (2017). Determinants of Corporate Social Responsibility (CSR) disclosure in developed and developing countries: a literature review. Corporate Social Responsibility and Environmental Management, 24(4), 273-294.

Alvarado-Herrera, A., Bigne, E., Aldas-Manzano, J., \& Curras-Perez, R. (2017). A scale for measuring consumer perceptions of corporate social 
responsibility following the sustainable development paradigm. Journal of Business Ethics, 140(2), 243-262.

Belal, A. R. (2016). Corporate Social Responsibility Reporting in Developing Countries: The Case of Bangladesh. London: Routledge.

Carroll, A. B. (1991). The pyramid of CSR: Toward the moral management of organizational stakeholders. Business horizons, 34(4), 39-48.

Carroll, A. B. (2016). Carroll's pyramid of CSR: taking another look. International journal of Corporate Social Responsibility, 3(1), 1-8.

Carroll, A.B (1999). Corporate Social Responsibility: evolution of a definitional construct. Business and Society, 38(3), 268-295

Cronin, A. (2018). Corporate Criminality and Liability for Fraud. London: Routledge.

Dahlsrud, A. (2008). How CSR is defined: an analysis of 37 definitions. Corporate Social Responsibility and environmental management, 15(1), 1-13

Devin, B., \& Richards, C. (2018). Food waste, power, and Corporate Social Responsibility in the Australian food supply chain. Journal of Business Ethics, 150(1), 199-210.

Edinger-Schons, L. M., Lengler-Graiff, L., Scheidler, S., \& Wieseke, J. (2018). Frontline employees as Community perception and oil companies' Corporate Social Responsibility (CSR) ambassadors: A quasi-field experiment. Journal of business ethics, 1-15

Frynas, J. G., \& Yamahaki, C. (2016). Corporate social responsibility: Review and roadmap of theoretical perspectives. Business Ethics: A European Review, 25(3), 258-285.

Gamu, J. K., \& Dauvergne, P. (2018). The slow violence of Corporate Social Responsibility: the case of mining in Peru. Third World Quarterly, 39(5), 959975.

Garriga, E., \& Melé, D. (2004). Corporate Social Responsibility theories: Mapping the territory. Journal of business ethics, 53(1-2), 51-71.

Gupta, A., Briscoe, F., \& Hambrick, D. C. (2017). Red, blue, and purple firms: Organizational political ideology and corporate social responsibility. Strategic Management Journal, 38(5), 1018-1040. 
Hasan, I., Kobeissi, N., Liu, L., \& Wang, H. (2018). Corporate Social Responsibility and firm financial performance: The mediating role of productivity. Journal of Business Ethics, 149(3), 671-688.

Husted, B. W., \& Allen, D. B. (2007). Corporate social strategy in multinational enterprises: Antecedents and value creation. Journal of Business Ethics, 74(4), 345-361.

Idemudia, U. (2007). Community perceptions and expectations: Reinventing the wheels of community perception and oil companies' Corporate Social Responsibility practices in the Nigerian Oil Industry. Business and Society Review, 112: 369-405

Idemudia, U. (2007). Community perceptions and expectations: reinventing the wheels of Corporate Social Responsibility practices in the Nigerian oil industry. Business and Society Review, 112: 369-405

Jamali, D., \& Karam, C. (2018). Community perception and oil companies' Corporate Social Responsibility in developing countries as an emerging field of study. International Journal of Management Reviews, 20(1), 32-61.

Kabote, S.J., \& Niboye, E. P. (2013), Socio-economic Effects of Large-Scale Gold Mining on Artisanal Miners in Tanzania: Experiences from Bulyanhulu Gold Fields, Dar es Salaam: Research on Poverty Alleviation (REPOA).

Loosemore, M., \& Lim, B. T. H. (2017). Linking corporate social responsibility and organizational performance in the construction industry. Construction management and economics, 35(3), 90-105.

Marika, N. M., Magutu, J. M., \& Munjuri, M. G. (2017). Corporate social responsibility and employer attractiveness among business students at the University of Nairobi, Kenya. International Journal of Arts and Commerce, 6(2), 71-88

Matten, D \& Moon, J (2008), "implicit" and "explicit" Community perception and oil companies' Corporate Social Responsibility: A conceptual framework for a comparative understanding of Community perception and oil companies' Corporate Social Responsibility. Academy of Management Review, 33 (2), 404-424.

Matten, D., \& Moon, J. (2008). "Implicit" and "explicit" Corporate Social Responsibility: A conceptual framework for a comparative understanding 
of Corporate Social Responsibility. Academy of management Review, 33(2), 404-424.

McWilliams, A., \& Siegel, D. (2001). Profit maximizing Corporate Social Responsibility. Academy of Management Review, 26(4), 504-505.

Moir, L. (2001). What do we mean by CSR?. Corporate Governance: The international journal of business in society, 1(2), 16-22.

Ni, A., \& Van Wart, M. (2015). Corporate Social Responsibility: Doing Well and Doing Good. In Building Business-Government Relations (pp. 175-196). Routledge.

Omair, A. (2015). Selecting the appropriate study design for your research: Descriptive study designs. Journal of Health Specialties, 3(3), 153.

Porter, M. E., \& Kramer, M. R. (2006). The link between competitive advantage and Corporate Social Responsibility. Harvard business review, 84(12), 78-92

Ramasamy, B., \& Yeung, M. (2009). Chinese consumers' perception of CSR (CSR). Journal of Business Ethics, 88(1), 119-132.

Ratner, S. R. (2001). Corporations and human rights: a theory of legal responsibility. Yale Law Journal, 111(3), 443-546

Rowe, K., Karg, A., \& Sherry, E. (2018). Community-oriented practice: Examining Community perception and oil companies' Corporate Social Responsibility and development activities in professional sport. Sport Management Review. https://doi.org/10.1016/j.smr.2018.05.001

Schmitz, J., \& Schrader, J. (2015). Corporate Social Responsibility: A microeconomic review of the literature. Journal of Economic Surveys, 29(1), $27-45$.

Schwartz, M. S \& Carol, A.B. (2003). Corporate Social Responsibility: a three domain approach, Business Ethics Quarterly, 13(4), 503-530. 